\title{
A MARANAO DICTIONARY
}





\section{A \\ MARANAO \\ DICTIONARY \\ Compiled by Howard P. McKaughan and Batua A. Macaraya}

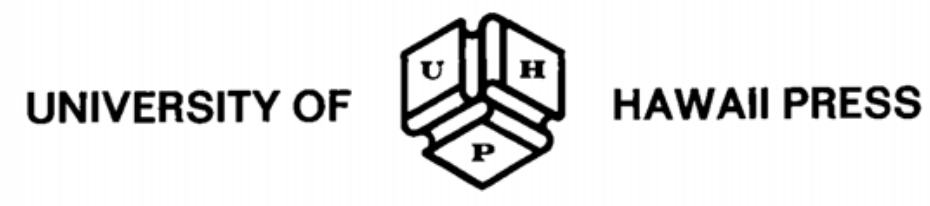

Honolulu 
Manufactured in the United States of America

Library of Congress Catalog Card No. 67-13668

First printing, 1967 